\title{
1994 - a temporal and scalar exploration of a Norwegian climax ${ }^{1}$
}

\author{
By \\ Haakon A. Ikonomou
}

\begin{abstract}
Through a temporal and scalar investigation of the two mediatized and jointly experienced events of the Lillehammer Winter Olympic Games (February 1994) and the Norwegian 'no' in a popular referendum to join the EU (November 1994), this article argues that '1994' marked a symbolic climax and watershed moment for Norwegian (cultural) patriotism and the globalization of what 'Norway' meant in a national, Nordic, European and world context. But the climax' meaning was fragmented across time and space, and the monolithic moment was at the time, and has increasingly since then come to be, filled with silences, anxieties and frustrations. Indeed, while the Lillehammer Olympics are essentially gone and impossible to recreate, an exasperated expansion of the parenthesis due to a desire to recreate this moment of Norwegian climax, is attempted by many actors in Norwegian society. Meanwhile, the most ardent 'yes' and 'no' segments of society ritually recreate their foundational narratives about Norway's place vis-à-vis Europe as part of two mutually exclusive, centuries old historical processes. This makes the negative 1994-referendum into a kind of non-moment. The simultaneous resurrection and burying of these twin events of the 1994-climax, this article argues, can be understood as catalytic: Producing a specific Norwegian mode of cultural and political myopia through a period of hasty, tumultuous, and troublesome globalization.
\end{abstract}

Keywords: Norway; Winter Olympics; global media events; globalization; European integration; Norwegian-EU relations; memories and narration.

Ikonomou, Haakon: "1994 - a temporal and scalar exploration of a Norwegian climax", Culture Unbound, Volume 13, issue 1, 2021: 160-187. Published by Linköping University Electronic Press: http://www.cultureunbound.ep.liu.se 


\section{Culture Unbound}

Journal of Current Cultural Research

The Olympic Winter Games in Lillehammer (February) and Norway's rejection of membership in the European Union by popular referendum (November) made 1994 a significant year in Norwegian history. Together with the Norwegian participation in the men's World Cup in football in the United States (June) and the awarding of the Nobel Peace Prize to Yasser Arafat, Shimon Peres and Yitzhak Rabin (October/December), the events repositioned Norway in a more affluent, confident and rapidly globalizing modernity. Taking place at the height of the linear television era, right before the proper onset of internet, the two events were experienced, shared and narrated in synchronicity by a large segment of the Norwegian people. Thus, '1994' was a shared experience in the local Norwegian context, but also an articulation of what the country was and was to be in the flux of the mid-1990s.

This article explores '1994' as a cultural-historical 'moment' in order to tease out the layered manifestation of 'Norway' in a globalizing world. Drawing on the oral testimonies, news coverage, reports, academic analysis and memories of people experiencing and contextualizing the two events of Lillehammer ' 94 and the EU referendum, the article pursues their meaning along several temporalities and on multiple spatial scales. The argument - which must remain tentative at this point - is that ' 1994 ' marked a symbolic climax and watershed moment for Norwegian (cultural) patriotism and the globalization of what 'Norway' meant in a national, Nordic, European and world context. But the climax's meaning was fragmented across time and space, and - as we shall see - the monolithic moment was at the time and has increasingly since then come to be filled with silences, anxieties and frustrations.

The first element of this approach enables us to explore the narration and negotiation of '1994' along the axis of temporality. Historians such as Alessandro Portelli argue that the very subjectivity of personal narrations is valuable to the study of historical experience and identity (Thomson 2010). Omissions and silences of personal memories can be made the object of historical inquiries (Christensen, Poulsen \& Smith 1998, Bak 2010, Chistensen, Poulsen \& Smith 2016). Further, subjectivity - or rather inter-subjectivity (Green 2010) - and the relationship between memory and forgetfulness can be brought to explore broader phenomena (Passerini 1984, 2005). Moreover, memories and narratives of the past are important bridges, constructing meaning between a recalled "then" and the context of "now" (or imagined future). Things that happen to us, the French philosopher Paul Ricoeur argues, are given meaning through a narrative 'emplotment' in which events are ordered to uphold the plot. Thus, narratives are constructed to create a meaningful 'self', but also a meaningful 'then', in the present (Ricoeur 1980, Hermansen \& Dahl Rendtorff 2002). These plots can arrange a life in a meaningful narrative, but we can also use it a bit more abstractly to 


\section{Culture Unbound}

explore how a multi-vocal collective negotiates a national self; or how journalists, scholars and others narrate a country, continent or world in transition. Exploring globalizing moments from this perspective allows us to hold together and analyse the interplay between several scales of time. History unfolds in several tempi, and this approach allows us to grasp how they interact with, and indeed produce, experienced time. For our purposes, this means that we can use the two events, and the way people analysed, narrated and remember them, as an entry point to explore the temporal manifestation of 'Norway' through the complex negotiations of shared cultural-political moments (Deleuze 1968/1994, Koselleck 1979, 2000). ${ }^{2}$

The second element of the approach allows us to explore the narration and negotiation of '1994' along the axis of scalarity. Scales are central to most global history writing. To avoid operating only on a highly structural level and to connect global processes to human experiences, historians have turned to scales as a way to explore the heterogeneity and entanglements of global phenomena in local contexts and vice versa. The aim here is to 'read' and 'place' the individual or collective narratives in several scales: local, national, regional, continental, global. All scales (can potentially) matter - and are interlinked - but we ultimately determine which are brought into play and how (Almagor, Ikonomou \& Simonsen 2022). In this way, narratives, testimonies and memories of people can be a sharp tool to unpack the concrete manifestation of global phenomena, and in our case, the globalizing of concrete events.

\section{Winter Olympics in Lillehammer}

Lillehammer '94 was perhaps the most important 'branding' moment in Norwegian history. It was the Norwegian Broadcasting Corporation's (NRK) largest TV-production until then, and it was seized upon as an opportunity to present the values, identity and story of Norway and the Norwegians. Promoting the host nation is - of course - one of the main aspects of the Olympic opening ceremonies in general. As John MacAloon argues, referring predominantly to the summer Olympics, “...no other anything has ever managed to generate regularly scheduled and predictable performances which command anywhere [near] the same focused global attention as do the Olympic ceremonies" (MacAloon 1996: 33). Lillehammer ' 94 was peculiar in the sense that it was the first winter Olympics held 'in-between' the summer Olympics - somewhat heightening the mediatized focus. Yet, we must remember that the reach of the winter Olympics is substantially less than the summer edition. In any event, few Olympic Games (OG) have been more saturated with national symbols and narratives than Lillehammer '94 way beyond the opening ceremony. It is not unusual that Olympic organizers are accused of overt political propaganda, writes sociologist Roel Puijk, however, 


\section{Culture Unbound}

Journal of Current Cultural Research

"[i]n Lillehammer the foreign television companies did not complain: the extra material was considered useful in conveying the general festive atmosphere in Lillehammer." (Puijk 2000: 314) It was not conveying a particular political system or project, but rather a historically-charged reading of the nation.

Equally, few organizing committees have been more conscious about the opportunity this moment presented. Very much in line with the aims of the local organizing committee, the Olympic Radio and Television Organization 1994 (ORTO94) - a subdivision of NRK - aimed to present Norway to the world, in terms of both culture and scenery. This resembled the organizing committee's international objective:

The Winter Games are intended to create a distinctive and favourable impression of Norway, to consolidate our position as a winter sports nation, to enhance respect for our values and the role we play in the international community and to promote interest in Norwegian business and industry (LOOC 1993: 10).

The opening ceremony included Vikings, the Crown Prince lighting the Olympic Fire, supernatural creatures from Nordic mythology and fairy tales [vettene, a catch-all term], soprano Sissel Kyrkjebø in the national costume [bunad] singing the Olympic Hymn, the Royal Guards, children playing Hardanger fiddle [hardingfele], and almost every single symbol of Norwegian identity imaginable meshed together in a grand and festive production. Indeed, Sissel Kyrkjebø became a national symbol in her own right due to her role in the Olympics, recording and performing the official Lillehammer '94 song, "Fire in your heart" [Se ilden lyse]. There was a big commotion when it became clear that she would not perform this song, but rather the Olympic Hymn, at the opening ceremony, with the public and the Norwegian record companies demanding that it was brought into the programme. As musician and media expert Kate Augestad wrote back then, "To deny her to perform [this song] during the opening ceremony was almost regarded as blasphemous, like a denial of the 'Norwegian' and distinctly unpatriotic" (Augestad 1994).

In the Rapport officiel des Jeux Olympiques d'hiver de Lillehammer 1994, Gerhard Heiberg - President of the Lillehammer Olympic Organizing Committee - wrote:

In short, our vision for the XVII Olympic Winter Games in Lillehammer was to organise an international festival and sports extravaganza based on genuine values. After 16 spectacular days with tremendous spectator attendance, wonderful winter weather and a successful formal and 


\section{Culture Unbound}

Journal of Current Cultural Research

informal cultural programme, we believe that we achieved our goals. The celebrations in which all of Norway and large parts of the world participated exceeded all expectations. We are proud that winterland Norway was able to present itself at its best - through our athletes and the tremendous enthusiasm of tens of thousands of cheering spectators. The international press covered the activities in Lillehammer more than any previous Olympics, and thousands of letters have come from television viewers all around the world thanking LOOC and the Norwegian people for a unique experience. [...] (Gerard Heiberg in Mjelde et. al. 1994: 5).

From the very beginning, the report insists, cultural activities were meant to play a key role in the staging of the Olympic Winter Games in Lillehammer. National and regional Norwegian culture was to be expressed through a number of different experimental and traditional genres. In close collaboration with many Norwegian cultural institutions, a programme was developed that featured Norwegian distinctiveness in combination with the best Norwegian and international capacities in the fields of music, theatre, arts and handicrafts (Heiberg 1994).

The official Olympic movie, created following Lillehammer '94, tied the event into an even more profound mythology - of nature - so deeply rooted in Norwegian identity, and the romantic differentiation between genuine Norwegianness and the decadent civilization of Continental Europe in the $19^{\text {th }}$ century (Sørensen 1998):

"Many centuries ago, after the last ice age, after many dark and insufferable winters, the warm waters of the Gulf Stream - like a friendly invading army - pierced the magnificent glaciers, and they crumbled with a roar, flooding the sea with icy waters. And as the ice melted the land rose, and its beginning is revered in the anthem they sing of their homeland - the words: For all this weather it rises forth. And they called it Norway: this land that has given us the explorations of the Vikings, the magnificent fjords, the land of the midnight sun, the land of the northern lights" (Greenspan 1994).

There is a prevalent emphasis on the 'genuine', which is not self-evident even though most Olympic ceremonies highlight the culture and history of the hosting nation. Beyond the earthly gains of increased tourism or exports, Lillehammer '94 was knitted together as a collective presentation of the authentic Norwegian soul. It is not clear what this entailed, rather it is significant that it was a focus (as opposed to strength, modernity, cultural prowess or something else). This construction, it seems, had to incorporate the egalitarian inclusion of broad 


\section{Culture Unbound}

segments of society, nature as a force of authenticity and purity, and symbols that gained a collective meaning as part of the protracted cultural and political process that detached Norway from Denmark and then Sweden, now renegotiated for a new time (Hylland Eriksen 1993: 2-4). ${ }^{3}$

\section{Lillehammer: The Scaled Breakdown of a Coherent 'Moment'}

This was the orchestrated narrative, created in the nexus between the IOC, the Norwegian organizers and the Norwegian media. However, how this story was created and understood and how the message 'Norway' tried to convey to the world was heard, needs to be unpacked.

Olympic Games are what Dyan and Katz call media events. They argue that "these broadcasts integrate societies in a collective heartbeat and evoke a renewal of loyalty to the society and its legitimate authority" (Dyan \& Katz 1992: 9). More recently, Maurice Roche has argued that OG and World Cups have overtaken the role of world fairs as mega-events and producers of global modernity and synchronicity (Roche 2000). Puijk, however, argues, that while the Norwegian people were "absorbed in a truly festive atmosphere during their duration", based on empirical studies "[o]ther countries neither covered the same event in the same way, nor made similar interpretations". Rather, the OGs should be treated as "a layered series of events of varying 'strength' and meaning" (Puijk 2000: 309). Accordingly, what happens is not "a single Olympic Ceremony as planned by the host organisers, but a multiplicity of Opening Ceremonies broadcast around the world; each constructed in unique ways depending on the commercial obligations, financial resources, geopolitical or cultural perspectives of the various broadcasting networks" (Rivenburgh 1991: 95, Puijk 1999). ${ }^{4}$ Events creating a deep response in the host nation are often deeply embedded in national discourses, which might contradict the notion that OG generates 'global' and shared meaning (Puijk 2000: 327). However, it is also true that global media productions in themselves create fragmented mediatized scripts out of an ostensibly coherent 'global moment. The largest branding effort in Norwegian history was - for all we know - pulverized on a global scale (though consumed in synchronicity).

The national experience could also be interpreted differently. In his analysis of the influence the Lillehammer Olympics had on the national construction of Norwegian identity, Berkaak has argued that the country was discursively transformed from a nation into a commodity sign:

It seems that the process of national construction in Norway with the XVII Winter Olympics at Lillehammer, has reached the moment 


\section{Culture Unbound}

at which the country discursively has been transformed from being a nation, i.e. an idea of an abstract community based on the shared feeling of particularity and difference, to becoming what Wernick calls a 'commodity sign' (...) for many actors the country is no longer thought of as a nation, but increasingly as a site of consumption with itself the prime community (Berkaak 1999: 72).

In this interpretation, the very construction and stylized consumption of national symbols - the Haakon and Kristin dolls (the official mascots), the Viking helmets, the trolls, the pins with rune symbols, the hats modelled on Norwegian folk costumes, etc. - fetishized 'Norway'. Norway and the many deliberately produced markers of its "genuineness" was consumed as a modern, capitalist commodity in an "end of history" context (Fukuyama 1989).

On a local scale, the Winter Olympics were, of course, a multitude of things. However, one crucial aspect of the event, overshadowed by the national narrative, was the local and regional commercial and infrastructural development. Inland Norway, where Lillehammer is located, had been through over a decade of deindustrialization and mild depression. Lillehammer was severely afflicted, particularly with the shutting down of the city's largest industrial workplace, the wood processing company Mesna Kartong. The surrounding cities, Hamar and Gjøvik (also hosts), experienced similar slumps in industrial employment. The 'new' industrial adventure - oil - was on the western coast, and Inland Norway was commonly referred to as lying in "the oil shadow". The idea of hosting the Winter Olympics came from the local, originally German, hotel owner Wolfgang Müller. He gathered local businesses to pitch "a wild idea" to the regional authorities. A study group, headed by Lillehammer's leading bank owner, concluded that hosting the Winter Olympics would lead to growth and investments, and long-term positive effects with regards to tourism. From the very beginning, human geographer Tor Selstad writes, the games "were not primarily about sports and experiences, but about regional development" (Selstad 2004: 32-35). In his own memoirs, Müller narrates himself as the local that first made an organised attempt to get the OGs to Lillehammer, but then was side-lined by the 'professional' organizers [LOOC] and bigger business, once the idea was picked up (Mæhre 2013). The local newspaper reports how Müller defiantly resisted such attempts, and still - in 2014 - was remembered as "the world's greatest German-born Lillehammer-patriot" (Henriksbø 2013). Müller - in his own words - was the instigator, victim and resister of global forces.

Thus, one may discern a process that is in fact rather familiar, a locally driven project with relatively limited and practical aims gains traction because these aims are packaged in a much broader (here national) set of tropes. This incites 


\section{Culture Unbound}

Journal of Current Cultural Research

a global-national machinery of professionals to uproot, upscale, multiply and mass produce its 'original' recipe - in the process altering it fundamentally - all the while fetishizing its 'authenticity' beyond comprehension. Lillehammer ' 94 as a localized experience and a global media event was prepared in this way and consumed very differently depending on 'location'. The tensions within and between the scaled manifestation of Lillehammer '94 also informs the way it was remembered and narrated along the temporal axis.

\section{Commemoration: When Does the Moment Begin and End?}

Lillehammer ' 94 were "the Best Olympic Winter Games ever", the IOC- president Juan Antonio Samaranch said at the closing ceremony. This has become a catchphrase which has allowed 'Norwegians' to endlessly expand the parenthesis of the moment, so that it could - potentially - last forever. However, it is also a statement with such finality, that it immediately makes the then-ness of the moment apparent. It can never be recreated. This makes it climatic: the constant commemoration of Lillehammer ' 94 harbours a certain uneasiness, oscillating between emotionally-charged nostalgia and an almost farce-like reproduction of what will never be again. ${ }^{5}$ This has charged consecutive debates about whether Norway should host the Olympics again.

It is worthwhile to recall that even though it now seems like Lillehammer '94 was an inevitability and - as the official Olympic movie conveyed - the product of Norway's natural forces profondes, there was nothing preordained about it. First of all, there were strong forces actively building momentum. The social anthropologist Arne Martin Klausen recalls how he:

[...] was invited to deliver an introductory lecture at a conference on Norwegian culture in an Olympic context, arranged by the Lillehammer Olympic Organising Committee (LOOC) in autumn 1989. I was given a title for the address which translated roughly into English as 'Norwegian Culture at a Ski-Jump Take-Off Point' (Norsk kultur på hoppkanten). Using this metaphor from ski jumping, the LOOC wanted to indicate that the Olympic Winter Games would provide Norwegian culture with the opportunity to soar to new heights (Klausen 1999: 1-2).

It is unclear what this 'soaring culture' was supposed to generate, apart from recognition. There are very few clear, material strategic aims to discern in any of the material, which leads one to conclude that it is the 'presentation' in itself that is the most important element. 


\section{Culture Unbound}

Journal of Current Cultural Research

In any case, a radical shift towards accepting the fact that Lillehammer had applied for the OGs occurred in the early 1990s, as if people were swept up by a finely orchestrated wave of enthusiasm. Following the games, well over 90 percent in a survey agreed with the statement: "Irrespective of what I thought about the Lillehammer Games, my enthusiasm was kindled during the Games" (Puijk 2000: 316). There can be little doubt that Lillehammer ' 94 created strong emotions within a large section of the Norwegian population that were directly tied in with the shared experience of the moment.

At some point, however, the Norwegian media, athletes and former and prospective organizers started eulogizing Lillehammer ' 94 . The mediatized commemoration follows a clear script: on the milestone anniversaries of the Lillehammer Olympics, leading figures from back then narrate the story, while 'regular people' are asked to share their memory of the event. Most of the online articles end with "WHAT IS YOUR MEMORY? - SHARE HERE" or something similar. Norwegians are 'triggered' to relive the joy; an insistence on the communality of the experience, but also a forced extension of the moment: it is still living inside all Norwegians - isn't it?

In 2009, NRK could thus report: "At 17:39 oclock today it is 15 years since Crown Prince Haakon Magnus lit the Olympic Fire. What's your memory from the Olympics?" Under the sub-heading “People only remember Lillehammer", Åge Dalby of the official Olympic Museum in Lillehammer tells us that " $[\mathrm{m}]$ ost people coming here are foreigners, and they are still enthusiastic. Nobody remembers Nagano in 1998, Salt Lake City in 2002 or Torino in 2006. It is Lillehammer they all remember". It is unsurprising that people having travelled to the Olympic Museum in Lillehammer and talking to Dalby might forefront that particular OG. However, even in Dalby's recollection, there is a sneaking ambivalence: "[The Olympic Games] affected most people in the city, whether they like it or not. People are by and large proud and happy about what happened fifteen years ago. At the same time, I guess there are some that are sick of all this talk about the Olympics, and just want their city back to the way it used to be" (Kjæstad 2009).

Equally, many of the Norwegian athletes participating in the Lillehammer Olympics have been eager proponents of a new Norwegian Winter Olympics ever since. But there is always the nagging notion that the moment - though it can be extended as a memory - can't be recreated. In a news piece from $2014-20$ years after Lillehammer ' 94 - the newspaper Verdens Gang could report that " 9 out of 9 of the Norwegian Olympic heroes from Lillehammer are positive to Oslo 2022." The cross-country skier Anita Moen Bonden remembered: "The Olympics at Lillehammer were definitely the best Olympic Games ever. All the foreigners say it too. No one forgets the mood, and on the relays we couldn't hear what the timers said, they had to use cardboards [with split times on]" (Anda \& Johannessen 2014). 


\section{Culture Unbound}

In February 2019, 25 years after the Winter Olympics in Lillehammer, the Norwegian Olympic Museum in Lillehammer materialized the nostalgia: Under the heading "From warm OG-memories to unbeatable woollen dresses", we are told that the museum in collaboration with a group of young designers, have reused the fabric of four old OG-sweaters to make eleven new woollen dresses. ${ }^{6}$ This nostalgia has, one could argue, made Lillehammer ' 94 a memory depository for 'a better time'. Much like NRK's slow-TV productions of Norwegian nature soared in the context of the global anxieties post-2008, Lillehammer '94 is a 'moment' that perhaps allows Norwegians to escape the present, but also imagine a place that is 'Norway' (Blunt 2003).

The Olympic Museum created a website where people could write in their memories of the Olympics. One man wrote that he flew from Trondheim to Oslo during the OGs, and that the captain chose to fly low over Lillehammer: "when we looked out of the small airplane windows, thousands of meters up in the air, one saw the entire area coloured in red, white and blue - and some other colours in between of course. I thought I could hear the sound from the arenas all the way up in the airplane, but I couldn't of course". A woman working as a volunteer in Lillehammer remembered having rehearsed for 400 hours to take part in the opening and closing ceremonies. It was cold, but the volunteers kept warm by jumping and rubbing up against each other. Right after the opening ceremony, "we were told that $O L-f l o k e^{8}$ dancers were needed in the city. We just had to change swiftly and get down to the city for new missions. [...] I don't think I reflected on how special it was to be a part of all this back then - young as I was - but afterwards I have come to realize what a fantastic experience it was. I hope I can experience it once more!" Another man - 9 years of age in 1994 - remembers seeing it on TV:

"I do not remember any disciplines or any winners, but I remember sitting at home in the living room with my grandfather and watching EVERYTHING that was aired. I got a piggy bank with [the official mascots] Kristin and Håkon, that I was proud of for many years (okay, I still have it). And pins. And caps. Caps with pins. All is stowed away in the attic at my grandmother's, and one day I will find it and show it to my daughter. [...] I remember how sad I was when it was all over and everybody went back to the way they used to be. Grey and sad, without the colours of villvettene [mythological creatures from the opening ceremonies]. Had I known back then that we would continue living on "OG 94" like we have done, maybe I wouldn't have taken it so hard back then." 


\section{Culture Unbound}

Journal of Current Cultural Research

So, what are they longing for? Heiberg would rave that the OGs were so successful because people cared and were conscious of the details: "Long after the OGs I met an American journalist that had been in Lillehammer. He talked about the details. When I asked him, if he could give an example, he answered: 'The yellow stains in the snow in the evening were gone when we came back in the morning, even if it hadn't snowed at all. People took responsibility on their own"' (Strøm 2019). The American 'witness' assures the reader that these narratives are not all in the 'Norwegian mind'. Nonetheless, nostalgia could swing towards desperation: In another interview, Heiberg argues that "Norway most definitely needs to get a new Winter Olympics. With a new Winter Olympic Games, we can once again show the world how this can be done for a reasonable price and magnificently. (...) The Lillehammer Olympics remain the best Winter Olympic Games ever. They still agree on this in the IOC (...) the atmosphere of the people [Folkestemningen], the attendance, enthusiasm and exaltation has not been seen in any other place" (Ritzau 2019). Again the IOC assures us that this is a global interpretation. However, now we need another OG to reclaim the purity of the moment back then. The commemoration - in other words - has taken on new levels of intensity and nostalgia, but also carries anxieties and ambivalences.

Marking the anniversary, NRK produced a series in 2019 looking back at the Olympics. The caption text is revealing:

'The best winter games ever', the IOC-president Samaranch said at the closing ceremony in 1994. Never had such words been used, before or after. But what made the games so special? What made Johann Olav Koss so good? Can the success ever be repeated? And - not least - will we ever stop humming the OL-floka. ${ }^{10}$

Others use memories of Lillehammer ' 94 to highlight the divisions this once shared moment has created. Ola Magnussen Rydje, a journalist at the national newspaper Dagbladet, commenting upon the repeated political struggles and regional in-fights to get a new Winter Olympics to Norway on the occasion of the $25^{\text {th }}$ anniversary of Lillehammer ' 94 , noted that the "fight over the Winter Olympics in Norway is more and more like the EU struggle. Let us unite the nation with something new." He connects this political analysis with his memories:

"I remember the Winter Olympics in Lillehammer in 1994 as a giant anti-climax. Almost disappearing in the sea of people, the restless, six-year old version of me waited for hours to catch a glimpse of the $30 \mathrm{~km}$. Or was it the relays? I don't remember. In any case, it was 20 degrees below zero, and nothing lived up to the expectations. It all went 


\section{Culture Unbound}

Journal of Current Cultural Research

by too fast, there wasn't any gold. I guess I was too young back then to get lost in an occasion of such magnitude as the Olympics. Not to speak of the joy of sports [idrettsglede] and national romanticism. I wanted to play in the snow, not freeze to three times 16,5 in Lysgårdsbakkene [scores in ski jumping]" (Rydje 2019).

Memories like these are productive. They are narrated to create sense in the present. It is, perhaps, the dissonance between the highly orchestrated then - with all its symbolic potency - and now that creates the need to extend the parenthesis, while perpetually re-producing the then-ness. Lillehammer '94, through a lot of sweat, toil, money and collective identity building managed to construct a moment where core Norwegian identity markers and the commercialized individualism of modern sports came together, for a brief moment, to create a sense of harmony (Klausen 1999) ${ }^{11}$, that was neither spatially nor temporally sustained. This is diametrically opposite of the EU referendum, which was an orchestrated and mediatized display of division back in 1994, reproduced by some, but plastered over by a massive administrative, legal and political silence upheld by a compromise solution that in fact strikes at the very core of Norwegian national identity.

\section{The EU-referendum}

The struggle over Norwegian membership in the European Union (EU), which culminated in an advisory (but in reality, binding) popular referendum in November 1994 was an intensely mobilizing, societal event, televised and mediatized, commented upon in real-time across Europe, but not something that engaged a 'global' audience. In many ways, it was a rerun of a debate about Norway's relationship with 'Europe' which had played out in the 1960s and early 1970s, when it ended with a negative referendum in September 1972. The divisions across the left-right spectrum were the same, the primary sectors of agriculture and fisheries posed similar dilemmas to the negotiators in Brussels as they had more than 20 years earlier, the way the "no" and "yes" campaigns organized followed the same logic as before. It was a paler, less bitter and divisive battle, but on familiar terrain (Tamnes 1997: 153-246).

Other things were new: Norway was more affluent, it had oil, it was not locked in Cold War dynamics, and through EFTA-membership it had moved closer to the continent in terms of trade and commercial regulations. The question in 1972 was whether Norway should follow Great Britain, Denmark and Ireland into the European Community (as it was called), in 1994 the question was whether Norway should follow Sweden, Finland and Austria (Switzerland choosing another path). 


\section{Culture Unbound}

Journal of Current Cultural Research

Remaining on the outside this time around would leave Norway much more isolated - at least in political terms. On the other hand, Norway - as the other applicants - had negotiated regulated access to the single market through the so-called European Economic Area (EEA), an agreement that went into force already in January 1994. Depending on who you asked, this arrangement was meant as a 'steppingstone' or a 'waiting room' to membership proper - an idea that had come about while the Cold War was still on. With the sudden collapse of the east-west order, this mechanism became redundant - or so it seemed. Because, with the Norwegian 'no' to membership in the EU in November 1994, the EEA remained intact and thus became the permanent (though evolutionary) solution to Norway's peculiar conundrum (Tamnes 1997, Rye 2017, Rye 2019, Ikonomou \& Gehler 2019).

With these protracted developments in mind, the question becomes: even if the referendum itself was a 'time-limited', mediatized event, was the November 1994 EU-referendum really a moment?

\section{Resisting Europe - A Temporal Argument}

I will limit the temporal analysis to a singular case, namely the many contradictory reflections and arguments about the meaning of the 1994-referendum that appeared around its 20-year anniversary in 2014, which simultaneously marked the 200-year anniversary of the Norwegian Constitution and Norway's secession from Denmark (only to be bound by a personal union with Sweden until 1905). What will become apparent is that the EU-referendum is deeply submerged in history, symbolism and almost divine teleology on both sides. Thus, the Norwegian 'no' is not a break. It is in fact almost a non-moment; a seamless continuation of an epic and lasting struggle of 'self-government'. Conversely, for the losing side, the negative result was the culmination of Norwegian narrowmindedness. The fool on the hill had done it again - just like in 1972 - trading perceived sovereignty, a mere cultural token of freedom, for real influence on the European and global stage. In this perspective, the current state of Norway's relationship with the EU amounts to 'Constitutional self-harm': Norway's non-membership, while accepting legislation from Brussels en masse with little political or public debate, fell in line with an even longer history of muted subservience to other European powers.

In one respect, the EU-referendum, like the EC-referendum in 1972, was a matter of discursive or rhetorical power: the ability to saturate one's interpretation with historically loaded symbols, institutions and words and the ability to establish, even institutionalize, and activate these interpretations in a way that influences political action (Neumann 2001). ${ }^{12}$ The People's Movement, organizing most of the no-side in 1972, and NO to the EU, doing the same in 1994, won 


\section{Culture Unbound}

Journal of Current Cultural Research

this discursive struggle. The choice boiled down to whether or not one wanted to retain 'self-government' (sjølstyre). The key to the no-side's success was their ability to communicate that the choice - harking back to Norway's secession from Denmark in 1814 - was between 'government by the people (folkestyre)' and 'government by remote elites'.

Accordingly, at the 200-year commemoration of the Constitution - in 2014 $N O$ to the $E U$ chose to celebrate a double-anniversary:

200 years since the Constitution and 20 years since the last «no» to the EU. The online text reads: «In 1814 government by the people meant the democratization of the Norwegian society, expressed by the people being the legislative power through the Parliament [Stortinget]. National sovereignty was hanging by a thread, but the men of Eidsvoll [where the Constitution was signed] showed the courage needed to secure the interests of the Norwegian people against the great powers. However, complete self-government was first won with the abolition of the union with Sweden in 1905. The Norwegian state is built on the principle of the sovereignty of the people. In 1994, the EU-struggle too was about government of the people versus government by remote elites. National sovereignty was again on the line, when the majority of the people once again rejected the idea that Norway, as a nation, could not look after its own interests in the world without being incorporated into the EU. 1814+1994 = true!" (Standpunkt 2014: 10-11).

This was a distilled version of the powerful narrative that remains the most important reason why Norway didn't join the EC/EU in 1972 and 1994, and why it remains on the outside today.

The 'no'-side's first ever slogan in a public campaign - back in 1961 - read: "When big decisions have been made in our country's history - in 1814, 1905 and 1940 - a unified people have stood behind the choice. These decisions make up the foundations of our country's social, economic and cultural progress in recent times and obliges our generation to carry this line through" (Dahl 2001: 11).

The referendum of 1972 was portrayed as that generation's historical moment to protect Norway's self-government - as in 1814, 1905 and 1940. Historian Hans Frederik Dahl concludes that "it is fair to maintain that this claimed historical continuity is the fundamental view of history of the no-side" (Dahl 2001: 11). Equally, social anthropologist and political scientist Iver B. Neumann argues that the no-side - in 1972 and in 1994 - succeeded in portraying Norway as divided between state and people, between bureaucracy and parliament. And that it was only the Storting (the Norwegian parliament), and not the bureaucracy, that was 


\section{Culture Unbound}

Journal of Current Cultural Research

legitimately connected to the nation. This is because democracy, as maintained by the Storting, was born with - and slowly emerged from - the Constitution of 1814; while the bureaucracy has historic ties to Denmark-Norway and the personal union with Sweden, making it suspicious, foreign and continental. Neumann concludes that in the Norwegian debate on 'Europe', the no-side has managed to place the terms people-Storting-sovereignty against the terms state-bureaucracyunion. Thus, in the referendum of 1994, a historically saturated 'sovereignty' stood against an equally negatively loaded 'union' (Neumann 2001).

Inherent in the word 'union' is the importance of protecting Norway from a dangerous or sick Europe: "We have strong ties to European culture. Here, we have both given and taken. However, Europe is two things: there is a Europe that has inspired our work for freedom, our democracy and our Constitution. But there is also a Europe responsible for wars of conquest, colonialism and oppression - economically and socially. There is a great danger that it is the latter of these currents that we will be drawn into, if we join the Common Market." This stands in marked contrast to Norway which, in the EU-debate of 1994, was characterized as such by a leading left-wing politician:

"We are more anti-authoritarian in Norway than many other places. We believe a bit more in equality and justice in Norway than one does many other places. Historically, we - in Norway - have had much weaker political and economic elites than many other places. We have no nobility in Norway. The civil servants got their political push-back from a strong people's movement of the last century, and in this century, we have had strong people's movements that have dominated our country in opposition to the elites. And yes, these Norwegian traits are part of what makes us one of the best countries in the world to live in - it is one of the best things about Norway" (Erik Solheim quoted in Neumann 2001: 154-155).

The result is a historically-informed dichotomy between 'Norway' and 'Europe' Europe being the designated Other, with all the traits that Norway is not. Norway had to protect itself against this pathological continent - a fight the Norwegian people had conducted since 1814 . This rhetoric had been prevalent - also in the Storting - since the EC-debates of the 1960s and 1970s. It is not a small irony, then, that Norwegian EU-politics today is almost completely de-politicized and mostly an administrative endeavor. Norwegian interests are routinely maintained by a gigantic bureaucratic and diplomatic machinery set up in Brussels, with little public debate or scrutiny.

To those arguing for membership in the EU, the referendum and the time that 


\section{Culture Unbound}

Journal of Current Cultural Research

has passed since took on a different meaning. Those that worked most closely with the negotiations - the assigned Norwegian diplomats - saw 1994 as a possibility to take part in a different long, historical trajectory: that of organized peace in Europe (Ikonomou 2015). With the second negative referendum, Norway had been shunted to the sidelines and "marginalized from the economic and political integration in Europe", as Norwegian chief negotiator Eivinn Berg later noted (Berg 2015). ${ }^{13}$ The diplomats, however, where not only frustrated by the choice of the Norwegian people, they were equally disappointed with the political elites that advocated in favour of membership, for not doing it with enough passion and on the right basis:

The big mistake of the Borten- and the Bratteli Government [of the 1960s and early 1970s] both was that they failed to come out and explain why the EU was created: never again war in Europe. I tried time and again, but it fell on deaf ears. And the Brundtland Government [of the 1990s] repeated this mistake, when the new negotiations started in the 1990s. I warned but was not heard (Holland 2013).

These pro-European diplomats of the Norwegian MFA were in a minority. As one such diplomat noted: "Trade policy is security policy, and that is the politics of peace. And that dimension was completely missing - wasn't even on the horizon in the Norwegian debate, neither in 72' nor in 94'" (Johannessen 2012). For the diplomats, the symbolic moment of importance was not 2014, but 2012, when the European Union received the Nobel Peace Prize. "Now, finally, the peace perspective is starting to come to the fore with the handing out of the Nobel Peace Prize", one of them noted (Holland 2013). While the argument had never gained much traction in the Norwegian EU-discourse - on either side - former editor of the conservative newspaper Aftenposten Per Egil Hegge noted in 2013, the Peace Prize was "a just and well-founded appreciation" for the most arduous pro-Europeans - parched for the recognition of their interpretation of history (Hegge 2014).

The more impactful remembrance and narration on the 'yes'-side is that Norway's negative referendum assigned the country to a marginal and undemocratic role in the European theatre. This was also prevalent in 2014, when the pro-Europeans mobilized against the ' $1814+1994=$ true'-campaign.

Head of the European Movement in Rogaland, Norway, Henrik Kvadsheim, wrote about the double-celebration: "These days, those opposed to the EU are celebrating that the Norwegian electorate said 'no' to membership in the EU 20 years ago. But what part of being on the outside is worth a toast?". Lamenting the amount of EU legislation that is imported without democratic debate, Kvadsheim also noted: "the Norwegian isolation boils down to fishery- and agricultural policy, 


\section{Culture Unbound}

Journal of Current Cultural Research

which makes food very expensive for Norwegian families compared to just about all countries in Europe. Is this benefit worth a toast?" His conclusion was that "hardly any other political subject exists in this country where the distance between rhetoric and reality on the ground is as big as in the EU-case" (Kvadsheim 2014).

In a newspaper article discussing the conflation of the Constitution and the 1994 referendum, then Director of ARENA, Centre for European Studies at the University of Oslo, Erik Oddvar Eriksen noted that the whole celebration left a bad taste in one's mouth: "Norway is for all intents and purposes a member of the union and pays for this membership via the EEA-funds but has no influence". One cannot wish the EU away, he argued, "[t]here is no alternative project on the horizon in the age of globalization. With all its flaws and shortages, the EU is here to stay." (Eriksen 2014a) In a publication on the same subject in the commemorative book 1814-2014 Red, White and Blue: Norwegian Constitution, American Inspiration, he made the same argument: Due to membership in the EEA, three quarters of EU legislation became Norwegian law too. Norway had effectively relinquished sovereignty on a number of policy areas without getting anything in return, such as co-determination as part of the EU institutions (Eriksen 2014b, 2014c). From a Norwegian constitutional perspective, he argued, Norway has increasingly lost its sovereignty with the evolution of the EEA-agreement. From a European constitutional perspective, Norway has thrown away its opportunity to influence the integration process and actually protect its national sovereignty and self-government. "This does not seem to concern anyone", he noted laconically, "1814 is celebrated in style by Norwegian officialdom, and 'No to the EU' is darting up and down the country to celebrate the 1994-referendum" (Eriksen 2014d). ${ }^{14}$

Eriksen was and is one of the most vocal critics of what he deems the "democratic self-harm" of living with the EEA-agreement, but he is also one of the standard bearers of a legal-academic-political spectrum that largely agrees in the analysis, but rarely states this publicly. ${ }^{15}$ Indeed, for pro-European politicians, the exercise (in 2014 and today) is an awkward defense of the EEA-agreement. As when former Minister of European Affairs Vidar Helgesen (Conservative) in 2014 argued that the agreement enjoyed strong legitimacy because a large majority of the Storting, and seven consecutive governments - across the political spectrum had supported and upheld it. While the access to the single market is undeniably crucial, Helgesen and others also need to defend the very limited access to the decision-making process that Norway enjoys:

The EEA-agreements allows us to influence the legislative process of the EU at an early stage, even though impact is not guaranteed. But this isn't guaranteed for member states either. We have openings, we have opportunities. And I must underline [...] the EU is a giant 


\section{Culture Unbound}

Journal of Current Cultural Research

communication- and negotiation machinery. If one gets in early, and have sound arguments, one is listened to (Standpunkt 2014: 13). ${ }^{16}$

This is a difficult argument to make and it is striking, for instance, that when the Brexit referendum was approaching, several Norwegian politicians suddenly started talking about the dire consequences of the EEA-agreement. Both representatives from the pro-membership party Høyre (Conservative) - including Vidar Helgesen himself - and the strongest opponent of membership, Senterpartiet (formerly the Agrarian Party, now a centrist, mostly rural party), were warning that the EEA-agreement was a poor solution. Høyre argued that Britain should remain in the EU to retain its influence, Senterpartiet that they should leave the EU completely, without undemocratic half-way solutions. Both were then, and are now after the realization of Brexit, of the opinion that the same applies to Norway (Ikonomou 2017).

This casts a very different light on the many years of EEA-acquiescence by shifting parliaments and governments: trapped in two fundamentally different ways of remembering, placing and narrating the 1994 referendum, they are nonetheless stuck in the same quagmire of historically loaded rhetoric, until now 'best' solved by a resounding silence on the issue - apart from the occasional theatrical commemorations, such as the one in 2014.

\section{Lost in EUphoria - The Drowning Out of a Resounding 'No'}

The EU referendum of 1994, while clearly important in a Norwegian context and certainly a matter of great interest for EC/EU negotiators, in some respects disappeared in the enormous geo-political tectonic shifts of the 1990s. If one looks at the historiography of EU enlargements, the 'enlargement round' that has received the least scholarly attention is the so-called EFTA-enlargement of the 1990s. It was bookended by the dramatic democratization and membership process of Greece (1981), Portugal and Spain (both 1986), on the one end, and the massive, 'big bang', 'return to Europe' of Central and Eastern European states on the other (2004/2007) (Ikonomou, Andry \& Byberg 2017).

Moreover, the EFTA-enlargement was literally overtaken by the fall of the Berlin wall and the hasty and haphazard transformation of the EC into the EU, with the Maastricht Treaty, negotiated in 1992 and coming into effect in 1993. The agreement on an economic and monetary union, including a single currency, a vague, yet significant, common foreign and security policy commitment and a third pillar of justice and home affairs - together with the prospect of a large-scale enlargement eastwards - signaled the emergence of 'Europe' as a global player. 


\section{Culture Unbound}

Indeed, in hindsight the 1990s and early 2000s, despite the many 'hiccups' marked an era of 'EUphoria'.

The American commentariat, for one, was rife with analysis of the EU as moral superpower and an economic powerhouse, that was at once a partner to the US and a challenger to its superior position in the world (together with China). At the crescendo of this EUphoria, in 2004, the American economic and social theorist Jeremy Rifkin argued that the European vision of society was eclipsing the "American Dream". Europeans had found a recipe for a better quality of life, and the EU was a model transnational government that would soon be followed by others: The European Dream would extend to the rest of the world creating a universal morality in its image (Rifkin 2004). The American interest was borne out of anxiety for what kind of 'beast' the EU was to become. In his 2003 classic Of Paradise and Power: America and Europe in the New World Order, Robert Kagan famously proclaimed that Americans are from Mars and Europeans from Venus. The post-Cold War had revealed a giant rift in the Atlantic order, with Europe now emerging as a political paradise of cosmopolitanism, liberal-democratic principles, human rights and international law. A Kantian vision that belied the US' Hobbesian world view (Kagan 2003).

It is not difficult to read what is now a rather dated 'happy-go-lucky' globalism into these interpretations. And only a few years later - starting with the Constitutional Crisis (2005) and then the protracted financial and economic crisis (2008 onwards), which has since been compounded with multiple other challenges (refugees, right-wing populism, pandemic to name a few), these kinds of narratives were seriously challenged. Indeed, the entire inevitability of the European project was challenged - in the streets and in the ivory towers of academia. Historian Mark Gilbert, in a now classic 2008-journal article, argued that it was high time to question the progressive, teleological story of European integration, where instances of 'non-integration' were narrated as obstacles and hurdles on the road to a European federation (Gilbert 2008). Nothing in recent history has made this more evident than Britain's choice to leave the EU (starting with the 2016 referendum and finalized on 31 January 2020). While the EU today is undeniably a global player; any signs of EUphoria have long passed.

But what was the meaning of the Norwegian 'no' in the context of the then emergence of 'Europe' as a global project? One striking feature was relative indifference, if not outright relief. The EFTAns had applied for membership at a moment when the European Community was concerned with the completion of the Economic and Monetary Union - in fact, the EEA was envisioned as a way of stalling any prospect of membership negotiations, at least until the 'deepening' had been completed. The end of the Cold War both accelerated this 'deepening' and made the push for membership stronger from Austria, Sweden, Finland and 


\section{Culture Unbound}

Journal of Current Cultural Research

eventually Norway. These were mostly affluent, democratic countries, and the problem of neutrality had receded into the background with the disappearance of the Soviet Union. Thus, the hurdles were relatively few. Moreover, due to the EEA negotiations, the applicants had resolved most of the difficult issues in what amounted to 'pre-accession' negotiations. Yet, the Norwegian people rejected membership, and it is worthwhile revisiting a news article - with a bit of distance, all the way from LA - that tried to give an immediate read on what had just happened:

For Europe, the impact of Norway's rejection is likely to be blunted. It follows strong 'Yes' votes in three other countries this year - Austria, Sweden and Finland - a development that means the EU will expand in January from 12 to 15 nations. While the Norwegian must be seen as a psychological setback for advocates of deeper European unity, some analysts argued Monday that it could be a blessing in disguise for them. Speaking before the results were announced, one Brussels-based political analyst said he was hoping for a 'no' vote. "I prefer Norway to say no, said Daniel Gross, a senior research fellow at the Center for European Policy Studies in Brussels. "They would be another problem country. It would be a help if they are not at the 1996 conference because they'd just put the brakes on.' In 1996, the EU is committed to a wholesale review of the Maastricht Treaty that commits member nations to political and economic union. That conference is expected to be a de facto constitutional convention. "In the end, this is going to make it tougher for Norway than for Europe," predicted Uwe Nerlich, deputy director of the Ebenhausen Institute, a German think tank near Munich. Certainly, conditions for Norway outside the EU are likely to be much more difficult than they were in the years after its 1972 rejection. With Sweden and Finland soon to be members, Norway risks being isolated from all its traditional Nordic partners. It would also be outside any EU defense union that might develop over the next few years (Marshall 1994).

In this interpretation, supported by several experts at the time, Norway was a nuisance and possible problem for the EU's plans for further integration. Moreover, the rejection was likely more problematic for Norway than for Europe, as it absorbed other Nordic countries. Many contemporary observers noted that Norway's 'no' could be a short-lived one: 


\section{Culture Unbound}

Journal of Current Cultural Research

By rejecting EU membership, Norway will be choosing a relatively prosperous - but possibly only temporary - isolation. Even some die-hard opponents admit that, if Sweden and Finland do well in the EU, they may reconsider the issue towards the end of the decade. [...] There is already a debate in Iceland and Switzerland about whether to apply to join the EU when it opens the door to more than a dozen would-be member states in central Europe and the Mediterranean after 1996. Supporters of membership point to the second Danish referendum in 1992, which reversed an earlier rejection of the Maastricht treaty, and predict something similar in three or four years. "I would be surprised to see the EU beginning accession negotiations with a range of countries once we have decided on reform of the EU institutions in the 1996 Maastricht review conference," one diplomat said in Brussels yesterday. "The Norwegians may have second thoughts by then about the wisdom of remaining in a splendid isolation - not primarily for economic, but for wider political and security reasons. I suppose they could come back again at that time" (Palmer 1994).

In both reports, the language of progress is striking, and just like Britain was 'missing the bus' of early European integration in the 1950s, Norway was missing [insert mode of transportation] of the emerging global power that was the EU in the 1990s. Soon, everyone would take part and it would be too late for Norway to join.

\section{Conclusion - Myopia in the Global}

"While [the EC-referendum of] 1972 was a defining generational experience, a landmark for an entire people, 1994 will first and foremost be remembered for the Winter Olympics in Lillehammer", writes Norwegian historian Rolf Tamnes (Tamnes 1997: 159).

Exploring '1994' along a temporal axis, this article has sought to show that two mediatized and collectively experienced events, that at the time mobilized many of the same historical, cultural and rhetorical tools, and articulated many of the same desires, images and expectations - the Lillehammer Olympic Games and the Norwegian EU-referendum - have since been remembered and narrated in very different ways. While the Lillehammer Olympics are essentially gone and impossible to recreate, an exasperated expansion of the parenthesis due to a desire to recreate this moment of Norwegian climax is attempted by many actors in Norwegian society. In a sense it is an attempt to recapture the perfect blend of imagined national purity. 


\section{Culture Unbound}

Meanwhile, as Hylland Eriksen and Neumann have argued, 'Europe' has become markedly less important for Norwegian identity. It is neither a prevalent simile nor marked other but has instead become an obscure figure of unknown proportions, despite the deep functional integration between Norway and the EU through the EEA-agreement (Hylland Eriksen \& Neumann). However, as shown, the most ardent 'yes' and 'no' segments of society ritually recreate their foundational historical narratives about Norway's place vis-à-vis Europe; whether in times of EUphoria or times of Brexit. Since the mid-1990s, however, these narratives have been kept down by methodical and awkward political silences, because every word spoken runs the risk of being caught in that same, sticky discursive web that has been spun since the 1960s. Thus, while Lillehammer was a moment continually, yet futilely, sought recreated; the referendum was a non-moment submerged in historic inevitability and strategic silence.

Along the scalar axis, the Norwegian climax of 1994 dissolved in commercialism, mediatized fragmentation, Europeanization and globalization. The recognition that neither the 'uniqueness' of the 'best Olympic Winter Games ever' nor the ideational and historical significance of the Norwegian 'no' was received as intended by the sender, makes their temporal manifestations in the national context all the more significant. The simultaneous resurrection and burying of these twin events of the 1994-climax can thus be understood as a significant catalyst of Norway's cultural and political myopia through a period of hasty, tumultuous and increasingly troublesome globalization.

\section{Author}

Haakon A. Ikonomou is Associate Professor at the Saxo Institute, University of Copenhagen. He is Gerda Henkel Fellow (2021-23) within the Special Programme "Security, Society, and the State", PI of the NOS-HS workshop series 'Scandinavian Internationalist Diplomacy, 1920s-1970s (2020-22), founder of Global Biography Working Group and Book Review and Online Media Editor of Diplomatica (Brill).

\footnotetext{
${ }^{1}$ Quotes from Norwegian newspapers, interviews, websites and publications have been translated into English by the author.

${ }^{2}$ Gilles Deleuze and Reinhart Koselleck are other (perhaps more famous) exponents of this kind of critical inquiry of time, memory and narration/action. Deleuze is more interested in how one can liberate fragments of time, that are not to be confused with actual memories, remove them from current of events, to get to the essence of what things are in the present and a possible future. Koselleck, meanwhile, is interested in human action and experienced time, which binds together layers of past experience with a
} 


\section{Culture Unbound}

Journal of Current Cultural Research

horizon of expectations in the productive now. Ricoeur is chosen for his analytical clarity, and because he is interested in narrative construction, while recognizing a clear inspiration from Koselleck.

${ }^{3}$ As the Norwegian social anthropologist Thomas Hylland Eriksen mused in 1993, "the only thing that keeps Norway together as a cultural community, is the incredibly strong interest in the phenomenon of 'Norway"' While tongue-in-cheek, Hylland Eriksen was genuinely concerned about Norwegian nationalism and the attempt to "freeze an authorized, official version of 'Norwegian culture. These efforts, to 'freeze in time' some version of Norway, were exasperated by globalization, Europeanization and the emergence of a multi-ethnic society. The great paradox, to his mind, was that any "hunt for the authentic" destroys what is in fact living culture: one starts to perform some pale variation of a constructed authentic 'self'.

${ }^{4}$ The quote and the secondary literature inspiration comes from Puijk 1999.

${ }^{5}$ It is no coincidence, that Norway's first Netflix original series, Lilyhammer (three seasons), follows the American gangster Frank Tagliano (Steven van Zandt) as he is sent to a witness protection programme in the sleepy, rule-bound, rural, naive and exotic community of Lillehammer. The choice is sparked by his faint memories of the cosy and magical Winter Olympic Games in Lillehammer in 1994 (and the beautiful women). The whole series is premised on a farcical cultural encounter to showcase, ridicule, but also admire imagined essential Norwegian traits. In a sort of meta-reflection of how Lillehammer 94 was the moment that Norway was 'presented' to the world, journalist Stein Erik Kirkebøen noted that Lilyhammer is "as big as the Lillehammer Olympics", because the series now was sold to 130 countries while the 1994 Winter Olympics were aired in 134 countries. It is the standard to which other attempts at selling Norway to the world are held. Stein Erik Kirkebøen, "Lilyhammer" like stort som Lillehammer-OL", Aftenposten, 26.10.2014. https://www.aftenposten.no/kultur/i/ngbyQ/lilyhammer-like-stort-som-lillehammer-ol.

${ }^{6}$ Norges Olympiske Museum "Fra varme OL-minner til makeløse ullkjoler” https://ol.museum.no/opplevelser/tidligere-utstillinger/fra-varme-ol-minner-til-makeloese-ullkjoler

${ }^{7}$ From a very different context.

${ }^{8}$ A song and dance created for the Olympic Games to keep the spectators warm in the freezing winter.

${ }^{9}$ All of the above is from: Sebastian Kühn "Minner. Stiftelsen Lillehammer Museum” https://minner.no/ tema/26.

${ }^{10}$ NRK “OL på Lillehammer”, https://tv.nrk.no/serie/olympiske-leker-tv.

${ }^{11}$ This is an interpretation of his argument.

${ }^{12}$ In the following, I will utilize some quotes and partly the perspective of this analysis.

${ }^{13}$ Eivinn Berg was chief negotiator at deputy level both in the European Economic Area- and the enlargement negotiations with the EC/EU in the 1990s.

${ }^{14}$ In 2014, "No to the EU" literally drove two customized vans across Norway, stopping at various locations, to celebrate the " $1814+1994=$ true" campaign and inform people about their work. STANDPUNKT 2-2014, 10-11.

${ }^{15}$ It should also be noted that his argument, that the EEA-agreement poses a democratic challenge to Norway, is largely confirmed in the official governmental report on Norway's relationship with the European Union published in 2012: Europautredningen: Utenfor og innenfor. Norges avtaler med EU, NOU nr. 2012.

${ }^{16}$ Referring a talk given by Vidar Helgesen at an ARENA seminar, 04.03.2014.

\section{References}

Almagor, Laura, Haakon A. Ikonomou \& Gunvor Simonsen (eds.) (2022, in press). Global Biographies. Manchester: Manchester University Press. 


\section{Culture Unbound}

Journal of Current Cultural Research

Anda, Kjetil R. \& Bjørn Arne Johannessen (2014): “OL-heltene fra 94: - Du får det ikke større”, 30 September 2014: https://www.vg.no/sport/i/k7W8j/ol-heltenefra-94-du-faar-det-ikke-stoerre (accessed 17.06.2021).

Augestad, Kate (1994). “Å, Sissel, Sissel, når eg ser deg slik," Norsk Medietidsskrift, 02.

Bak, Sofie Lene (2010). Ikke noget at tale om. Danske jøders krigsoplevelser, 1943-1945. Copenhagen: Museum Tusculanum.

Berg, Eivinn (2009): “Norges nei til EU - 15 år etter”, Minervanett, 15 December 2009: http://www.minervanett.no/norges-nei-til-eu-\%E2\%80\%93-15-ar-etter/ (accessed 08.04.2015).

Berkaak, Odd Are (1999): “Megalomania," Arne Martin Klausen and Roel Puijk (eds.): OL 94 og forskningen Østlandsforskning/NAVF: Lillehammer/Oslo.

Blunt, Alison (2003): "Collective Memory and Productive Nostalgia: Anglo-Indian Homemaking at McCluskieganj," Environment and Planning D: Society and Space, 21(6), 717-738.

Christensen, Claus Bundgård, Niels Bo Poulsen \& Peter Scharff Smith (1998). Under Hagekors og Dannebrog. Danskere i Waffen-SS. Copenhagen: Aschehoug.

Christensen, Poulsen, Smith (2016): "Samtaler om vold," Sofie Lene Bak (ed.): Oral History i Danmark, Odense: Syddansk Universitetsforlag, 47-55.

Dahl, Hans Fredrik (2001): "Norge på en ny måte. Forord," Iver B. Neumann: Norge. En kritikk, Oslo: Pax.

Deleuze, Gilles (1968). Différence et répétition. Paris: Presses Universitaires de France.

Deleuze, Gilles (1994). Difference and Repetition (Trans. P. Patton). New York: Columbia University Press.

Dyan, Daniel \& Elihu Katz (1992). Media Events: The Live Broadcasting of History. Harvard: Harvard University Press.

Eriksen, Erik Oddvar (2014): “The EU and the Norwegian Paradox: Bicentennial of the Constitution with an Aftertaste," Gudleiv Forr (ed.): 1814-2014 Red, White and Blue: Norwegian Constitution, American Inspiration, Oslo: ART PRO Forlag As, 250-259.

Eriksen, Erik Oddvar (2014): “All makt i denne sal?”, ARENA Blog, 20 January 2014: https://www.sv.uio.no/arena/personer/vit/erikoer/blogg/2014/all-makti-denne-sal.html (accessed 17.06.2021).

Eriksen, Erik Oddvar (2014): “Jubileum med bismak", Dagbladet, 03 March 2014: https://www.dagbladet.no/kultur/jubileum-med-bismak/60211928 (accessed 17.06.2021).

Eriksen, Erik Oddvar (2014): "Kronikk: Demokratisk selvskading", VG, 04 November 2014: https://www.vg.no/nyheter/meninger/i/5xRqW/kronikkdemokratisk-selvskading (accessed 17.06.2021). 


\section{Culture Unbound}

Journal of Current Cultural Research

Fukuyama, Francis (1989). “The End of History?” The National Interest (16), 3-18. Gilbert, Mark (2008): "Narrating the Process. Questioning the Progressive Story of European Integration," Journal of Common Market Studies, 46:3, 641-662.

Green, Anna (2010): "Can Memory be Collective?" Donald A. Ritchie (ed.) The Oxford Handbook of Oral History, Oxford: Oxford University Press, 96-111.

Greenspan, Bud (1994): “Lillehammer '94: 16 Days of Glory”. https://olympics. com/en/original-series/episode/lillehammer-1994-official-film-lillehammer94-16-days-of-glory (accessed 17.06.2021).

Hegge, Per Egil (2014): “Ja-sidens EU-kamp”, Minervanett, 23 December 2014: http://www.minervanett.no/ja-sidens-eu-kamp/ (accessed 09.04.2015).

Henriksbø, Per Ivar (2013): "Wolgang Müller forteller sin egen OL-historie", Gubrandsdølen Dagningen (GD), 23 October 2013: https://www.gd.no/nyheter/ wolfgang-m-ller-forteller-sin-egen-ol-historie/s/1-934610-6937218 (accessed 17.06.2021).

Hermansen, Mads \& Jacob Dahl Rendtorff (eds.) (2002). En hermeneutisk brobygger, tekster av Paul Ricœur. Aarhus: Klim.

Holland, Arild (2013): "Interview 20.02.2013", Haakon A. Ikonomou.

Hylland Eriksen, Thomas (1993). Typisk norsk. Essays om kulturen i Norge. Huitfelt: Oslo.

Hylland Eriksen, Thomas \& Iver B. Neumann (2011): "Fra slektsgård til oljeplattform: Norsk identitet og Europa," Internasjonal Politikk, 69:3, 413-436.

Ikonomou, Haakon A. (2011): "To Remember like a Diplomat", TEMP, Tidsskrift for historie, 6:11, 50-78.

Ikonomou, Haakon A., Aurélie Andry and Rebekka Byberg (eds.) (2017). European Enlargement Across Rounds and Beyond Borders. London: Routledge.

Ikonomou, Haakon A. (2017): "Et skudd i EØS-foten", NRK Ytring, 17 August 2017: https://www.nrk.no/ytring/et-skudd-i-eos-foten-1.13643104 (accessed 17.06.2021).

Ikonomou, Haakon A. \& Michael Gehler (2019): "The Accession of Austria, Sweden and Finland," Vincent Dujardin et al. (eds.): The European Commission, 1986-2000. History and Memories, Brussels: Office for Official Publications of the European Communities, 515-527.

Johannessen, Terje (2012): "Interview 24.04.2021), Haakon A. Ikonomou.

Kagan, Robert (2003). Of Paradise and Power: America and Europe in the New World Order. New York: Alfred A. Knopf.

Kirkebøen, Stein Erik (2014): “'Lilyhammer' like stort som Lillehammer-OL", Aftenposten, 26 October 2014: https://www.aftenposten.no/kultur/i/ngbyQ/ lilyhammer-like-stort-som-lillehammer-ol (accessed 17.06.2021). 


\section{Culture Unbound}

Journal of Current Cultural Research

Kjæstad, Reidar (2009): "15 år sidan OL på Lillehammer", NRK.no, 12 February 2009: https://www.nrk.no/innlandet/15-ar-sidan-ol-pa-lillehammer-1.6477424 (accessed 17.06.2021).

Klausen, Arne Martin (1999): “Introduction," Arne Martin Klausen (ed.): Olympic Games as Performance and Public Event. The Case of the XVII Winter Olympic Games in Norway, New York: Berghan Books.

Klausen, Arne Martin (1999): "Norwegian Culture and Olympism: Confrontations and Adaptations," Arne Martin Klausen (ed.): Olympic Games as Performance and Public Event. The Case of the XVII Winter Olympic Games in Norway, New York: Berghan Books, 27-48.

Koselleck, Reinhart (1979). Vergangene Zukunft: Zur Semantik geschichtlicher Zeiten. Frankfurt am Main: Suhrkamp.

Koselleck, Reinhart (2000). Zeitschichten: Studien zur Historik. Frankfurt am Main: Suhrkamp.

Kvadsheim, Henrik (2014): "Lite å skåle for", Europabevegelsen, 28 November 2014: https://www.europabevegelsen.no/lite-skale/ (accessed 17.06.2021).

Kühn, Sebastian: "Minner. Stiftelsen Lillehammer Museum" https://minner.no/ tema/26 https://minner.no/tema/26 (accessed 17.06.2021).

Lillehammer Olympic Organizing Committee (1993), Report.

MacAloon, John J. (1996): "Olympic Ceremonies as a Setting for Intercultural Exchange.” Miquel de Moragas Spa, J. J. MacAloon \& M. Llinnés (eds.): Olympic Ceremonies, Historical Continuity and Cultural Exchange, IOC: Lausanne.

Marshall, Tyler (1994): "Norway's Voters Reject Joining", The Los Angeles Times, 29 November 1994: https://www.newspapers.com/image/157255461/?terms=N orway\%27s\%20Voters\%20Reject\%20Joining\&match=1 (accessed 16.06.2021).

Mjelde, Helge et. al. (1994-1995). Rapport officiel des Jeux Olympiques d'hiver de Lillehammer 1994 [Official report of the Olympic Winter Games Lillehammer 1994] Vol 1-4. Lillehammer: LOOC. https://library. olympic.org/Default/doc/SYRACUSE/64685/official-report-of-the-xviiolympic-winter-games-lillehammer-1994-helge-mjelde-et-al?lg=en$\mathrm{GB} \# \mathrm{ga}=2.206932435 .1984822904 .1571225739-1225513626.1571225739$ (accessed 17.06.2021).

Mæhre, Liv Maren (2013): Wolfgang Müller. Mitt liv i Norge. Self-published.

Neumann, Iver B. (2001). Norge. En kritikk. Oslo: Pax.

Norges Olympiske Museum: "Fra varme OL-minner til makeløse ullkjoler".

https://ol.museum.no/opplevelser/tidligere-utstillinger/fra-varme-ol-minner-tilmakeloese-ullkjoler (accessed 17.06.2021).

NRK nett: “OL på Lillehammer", https://tv.nrk.no/serie/olympiske-leker-tv. (accessed 17.06.2021). 


\section{Culture Unbound}

Journal of Current Cultural Research

NOU 2012:2: Utenfor og innenfor: Norges avtaler med EU, Oslo: Utenriksdepartementet.

Palmer, John (1994): "Norway ready to reject EU”, The Guardian, 24 November 1994: https://www.newspapers.com/image/260856179/?terms=Norway $\% 20$ ready\%20to\%20reject\%20EU\&match=1 (accessed 16.06.2021).

Passerini, Luisa (1984). Torino operaia e fascismo. Una storia orale. Rome-Bari: Laterza.

Passerini, Luisa (2005). Memory and Utopia. The primacy of intersubjectivity. London: Routledge.

Puijk, Roel (1999): “OL - en global mediebegivenhet?”, Norsk Medietidsskrift, 01:06.

Puijk, Roel (2000): "A Global Media Event? Coverage of the 1994 Lillehammer Olympic Games," International Review for the Sociology of Sports, 35/3, 309-330.

Ricoeur, Paul (1980): "Narrative and time", Critical Inquiry 7(1), 169-190.

Rifkin, Jeremy (2004). The European Dream: How Europe's Vision of the Future Is Quietly Eclipsing the American Dream. New York: Jeremy P. Tarcher.

Ritzau (2019): "Nordmænd drømmer om gentagelse af OL i Lillehammer", 11 February 2019: https://www.avisen.dk/nordmaend-droemmer-om-gentagelseaf-ol-i-lillehammer537788.aspx. (accessed 17.06.2021).

Rivenburgh, Nancy (1991): “Learning About Korea - Or Did We?” Fernand Landry, Marc Landry, Magdeleine Yerlès, the International Olympic Committee (eds.): Sports, The third millennium: Proceedings of the International Symposium, Quebec City, Canada, May 21-25, 1990, Les Presses de l'Université Laval:Sainte-Foy.

Roche, Maurice (2000). Mega-events and modernity: Olympics and Expos in the growth of global culture. London: Routledge.

Rydje, Ola Magnussen (2019): "Vi bør skrote en ny, norsk OL-søknad", 13 February 2019: https://www.dagbladet.no/kultur/vi-bor-skrote-en-ny-norskol-soknad/70759549 (accessed 17.06.2021).

Rye, Lise (2017): "Integration from the Outside: The EC and EFTA from 1960 to the 1995 enlargement," Haakon A. Ikonomou, Aurélie Andry \& Rebekka Byberg (eds.): European Enlargements. Across Rounds and Beyond Borders, London: Routledge.

Rye, Lise (2019). Norge i Europa. Bergen: Fagbokforlaget.

Selstad, Tor (2004): "Regional dynamikk og Olympisk retorikk: Vinterlekene på Lillehammer ti år etter," Plan, 04:36, 32-35.

Standpunkt (2014): "The official journal of the NO to the EU movement", 2.

Strøm, Ole Kristian (2019): "25 år i dag siden Lillehammer-OL åpnet: - Ingen har klart å matche oss", 12 February 2019: https://www.vg.no/sport/i/G1WA2J/25aar-i-dag-siden-lillehammer-ol-aapnet-ingen-har-klart-aa-matche-oss. (accessed 17.06.2021). 


\section{Culture Unbound}

Journal of Current Cultural Research

Sørensen, Øystein (Ed.) (1998). Jakten på det norske: perspektiver på utviklingen av en norsk nasjonal identitet på 1800-tallet. Oslo: Gyldendal.

Tamnes, Rolf (1997). Oljealder. Oslo: Universitetsforlaget.

Thomson, Alistair (2010): "Memory and Remembering," Donald A. Ritchie (ed.): The Oxford Handbook of Oral History, Oxford: Oxford University Press, 79-82. 